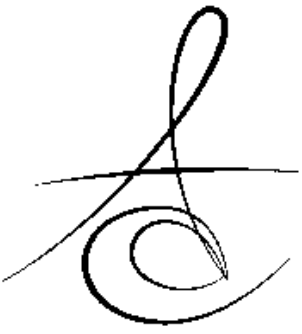

\title{
EVALUATION OF MECHANICAL AND FLUORIDE RELEASE PROPERTIES OF A BIOACTIVE GLASS ADDED GLASS IONOMER BASED FISSURE SEALANT
}

\section{BİYOAKTİF CAM İLAVE EDİLMİŞ CAM İYONOMER ESASLI FİSSÜR ÖRTÜCÜNÜN MEKANİK VE FLORİD SALINIM ÖZELLİKLERINNİN ARAŞTIRILMASI}

\author{
Dr. Öğr. Üyesi Emre KORKUT* \\ Dr. Öğr. Üyesi Murat S. BOTSALI** \\ Prof. Dr. Yağmur ŞENER*
}

Makale Kodu/Article code: 3515

Makale Gönderilme tarihi: 14.12.2017

Kabul Tarihi: 14.02.2018

\section{ABSTRACT}

Aim: Bioactive glass has a wide range of medical and dental applications and is a potential filler component for dental restorative materials. The aim of this study was to examine the influence of adding bioactive glass to glass ionomer based fissure sealant on its mechanical properties and fluoride releasing ability.

Material and Methods: Two experimental groups were prepared with BAG added to the powder component of the material at different ratios of \%30 (BAG30) and \%10 (BAG10) by weight. The glass ionomer based fissure sealant material without the addition of BAG was determined as the control group. Cylindrical shaped specimens $(8 \mathrm{~mm} \times 2 \mathrm{~mm})$ were prepared from each group. Fluoride release, surface roughness and surface microhardness of the specimens were measured and the data were statistically analyzed using one way ANOVA and Wilcoxon Signed Rank tests.

Results: There was no difference between fluoride releases of the materials except the first two days. BAG30 showed the highest surface microhardness and surface roughness values. There was no significant difference between surface microhardness values of BAG30 and BAG10.

Conclusion: The results of the study showed that adding BAG did not adversely affect the mechanical and fluoride release properties of glass ionomer based fissure sealants.

Keywords: Bioactive glass, fluoride release, surface roughness, surface microhardness

\section{öz}

Amaç: Biyoaktif cam, medikal ve dental uygulamalarda geniş bir kullanım alanına sahiptir ve dental restoratif materyaller için potansiyel bir doldurucu bileşendir. Bu çalışmanın amacı, cam iyonomer esaslı fissür örtücüye biyoaktif cam ilave edilmesinin, materyalin mekanik ve florid salınım özellikleri üzerine etkilerini araştırmaktır.

Gereç ve Yöntem: Cam iyonomer esaslı fissür örtücünün toz kısmına ağırlıkça $\% 30$ (BAC30) ve $\% 10$ (BAC10) oranlarında biyoaktif cam ilave edilerek iki farklı deney grubu elde edildi. Biyoaktif cam ilave edilmeyen materyal ise kontrol grubu olarak belirlendi. Her grup için $(8 \mathrm{~mm} \times 2 \mathrm{~mm})$ silindir şeklinde örnekler hazırlandı. Tüm örneklerin florid salınım değerleri, yüzey pürüzlülükleri ve yüzey mikrosertlikleri belirlenerek, veriler tek yönlü ANOVA ve Wilcoxon Signed Rank testleri kullanılarak istatistiksel olarak analiz edildi.

Bulgular: İlk iki gün yapılan ölçümler haricinde, tüm günlerde yapılan ölçümlerde materyallerden yapılan florid salınım miktarları arasında anlamlı bir fark olmadığı bulundu. En yüksek yüzey pürüzlülüğü ve yüzey mikrosertlik değerlerinin BAC30 grubunda olduğu gözlendi. BAC30 ve BAC10 gruplarında gözlenen yüzey pürüzlülüğü ve yüzey mikrosertlik değerleri arasında istatistiksel olarak anlamlı bir fark gözlenmedi.

Sonuç: Çalışmadan elde edilen sonuçlar, biyoaktif cam ilave edilmesinin cam iyonomer esaslı fissür örtücü materyalin mekanik ve florid salınım özelliklerini olumsuz yönde etkilemediğini göstermiştir.

Anahtar Kelimeler: Biyoaktif cam, florid salınımı, yüzey pürüzlülüğü, yüzey mikrosertliği

* Necmettin Erbakan, Dişhekimliği Fakültesi, Pedodonti AD, Konya
${ }^{* *}$ Selçuk Üniversitesi, Dişhekimliği Fakültesi, Pedodonti AD, Konya 


\section{INTRODUCTION}

Fissure sealants are commonly used in dentistry in order to prevent the development of dental caries. Fluoride releasing materials have been frequently preferred as fissure sealant such as glass ionomer cements (GIC), resin modified GICs, fluoride releasing resin based materials or adhesives. ${ }^{1}$ Most of the fissure sealants used today are resin based materials due to their higher retention rates. Nevertheless, resin based fissure sealants have lower level of fluoride release and require high precision during application in a moist environment. ${ }^{1,2}$ Considering the commercially available fluoride releasing materials GICs have the highest amount of fluoride release and represent an alternative to resin based materials especially in sealing the fissures of a newly erupted molar or where the isolation of moisture hampers for the treatment. ${ }^{3-5}$

GICs have been widely used in dentistry since early 1970s. They have many advantages in clinical usage such as chemical adhesion to dental hard tissues, high amount of fluoride release, biocompatibility and similar thermal expansion properties to that of dental tissues. Although, GICs often used in restorative and preventive dentistry, they have some major disadvantages, too. The most import insufficiency of GICs is the inadequate strength and toughness. ${ }^{3,4}$ Accordingly, several attempts have been made to overcome these limitations and improve the mechanical properties of GICs. ${ }^{4,6}$

Bioactive glasses (BAG) were firstly introduced by Hench et al. in 1969. Generally, BAGs contain oxides of calcium, sodium, phosphorus and silicon with different chemical composition and different proportion that provides the materials surface activity. ${ }^{7}$ BAG was initially used as bone substitute biomaterial in the human body. These materials are biocompatible and can bind to the hard tissues of the body. They react with aqueous solutions and produce a carbonated apatite layer that provides the stimulation of hard tissue formation and mineralization. ${ }^{7,8}$ Besides, there is a great number of studies demonstrating the antibacterial qualities of different BAG compositions. ${ }^{9,10}$ Therefore, these materials are considered to be successful in remineralization of dental hard tissues and prevention of dental caries. Consequently, BAGs has been used in dentistry with the aim of treating the dentinal hypersensitivity and the BAG particles have been incorporated into different types of dentifrices. Considering the remineralizing and antibacterial properties of these materials, BAG is thought to be a potential additive for dental restorative materials. ${ }^{10,11}$ Some recent studies have evaluated the incorporation of BAG particles into GIC to improve the bioactivity and remineralization capacity. ${ }^{12-14}$ The null hypothesis of this study was that incorporation of BAG particles into glass ionomer based fissure sealants would result in significant improvements in the fluoride releasing and mechanical properties compared to those of glass ionomer based sealants without BAG particles. Therefore, the aim of this study was to evaluate the amount of fluoride release, surface roughness and surface hardness of the glass ionomer based fissure sealant material incorporated with different proportions of BAG particles.

\section{MATERIAL AND METHODS}

In the present experimental study, a commercially available glass ionomer based fissure sealant (NovaGlass-F, Imıcryl, Konya, Turkey), which is consisted of powder and liquid and chemically cured was used. In addition, a commercially available bioactive glass (BAG) (Bonalive, Vivoxid Ltd, Turku, Finland) was used, which is a synthetic graft material. BAG is also known as S53P4 with a chemical composition of $\mathrm{SiO}_{2} \% 53, \mathrm{Na}_{2} \mathrm{O} \% 23, \mathrm{CaO} \% 20$, and $\mathrm{P}_{2} \mathrm{O}_{5} \% 4$ by weight.

\section{Preparation of specimens}

The BAG powder was added to the GIC powder at two different ratios of $10 \%$ and $30 \%$ by weight. The powder was mixed and milled with a zirconium ball mill (Pulverisette, Fritsch $\mathrm{GmbH}$, Germany). The particle size of the powder was set to $\leq 10 \mu \mathrm{m}$ with an average size of $0,7 \mu \mathrm{m}$. The experimental groups were described as; GIC with 30\% BAG (BAG30), GIC with $10 \%$ BAG (BAG10) and GIC without BAG particles (control group).

The materials were mixed according to the manufacturer's instructions and placed in teflon molds (with an inner diameter of $8 \mathrm{~mm}$ and a height of 2 $\mathrm{mm}$ ) in order to form cylindrically shaped specimens. After placement of the specimens in the mold, excess material was removed with finger pressure between two glass slides. Specimens were removed from the 
mold after one hour and stored in deionized water at $37^{\circ} \mathrm{C}$ during the entire experimental period.

\section{Determination of fluoride release}

A total of 60 specimens (20 from each group) were used in the study to determine the amount fluoride release from materials. A fluoride ion selective electrode (Model: 9609 BN, Orion Research, Boston, MA), connected to an ion analyzer (Model 720A, Orion Research, Boston, MA) was used for the measurements. Prior to each measurement, the fluoride electrode was calibrated using four standard solutions; $0.1 \mathrm{ppm}, 1 \mathrm{ppm}, 10 \mathrm{ppm}$ and $100 \mathrm{ppm}$. The specimens were stored in individual plastic tubes containing $4 \mathrm{~mL}$ of deionized water at $37^{\circ} \mathrm{C}$. The measurements were performed during a mixing procedure with a magnetic stirrer by adding total ionic strength adjustable buffer (TISAB) to the storage solution at a ratio of $1: 1$. Fluoride concentrations were automatically displayed on ion analyzer and recorded as a unit of ppm. The storage solution was refreshed after all measurements at days 1, 2, 7, 14, 21 and 28.

After the measurement at day 28 , all specimens were removed from storage solution and recharged with fluoride by applying APF gel (Topex, Sultan, USA) for 4 minutes. The measurement protocols were repeated at days 29, 35 and 42 .

\section{Surface microhardness}

Twenty cylindrically shaped specimens from each group $(n=20)$ were prepared for surface microhardness and surface roughness tests as described previously. Prior to the microhardness measurements; specimens were stored in individual plastic tubes containing deionized water at $37^{\circ} \mathrm{C}$ for a week. Measurements were performed using a Vicker's microhardness measuring instrument (MMT - X7, Matsuzuwa, Tokio, Japan) under a static load of $100 \mathrm{~g}$ with a dwell time of $15 \mathrm{~s}$. Each specimen was subjected to three measurements, and the mean VHN (Vicker's hardness number) value was recorded.

\section{Surface roughness}

For the surface roughness test, 20 specimens from each group $(n=20)$ were used. All specimens were polished with aluminum oxide abrasive discs before measuring the surface roughness. The surface roughness of each specimen was measured using a surface profilometer (Surftest 211, Mitutoyo, Tokio, Japan). The cut-off value for surface roughness was set at $0.8 \mathrm{~mm}$, and the traversing range of the stylus was $4.0 \mathrm{~mm}$. The average value of the peaks and valleys of the specimen surface was recorded as average roughness $\left(R_{a}\right)$. Three readings were taken at different locations and mean values were calculated for each specimen.

\section{Statistical Analysis}

One-way analyzes of variance (ANOVA) with Wilcoxon Signed Rank test was used to determine the significant difference between the fluoride measurements released from experimental materials. Level of significance was set at $p=0.05$.

In addition; results of the surface microhardness and surface roughness tests were statistically analyzed using one-way ANOVA at $p<0.05$ significance level

\section{RESULTS}

\section{Fluoride release properties}

The means and standard deviations of fluoride release of each group on different days are shown in Table 1. Highest amount of fluoride was obtained during the first day but mean values of fluoride release exhibited a significant decrease from day 1 to day 42 for all experimental groups. BAG30 and BAG10 showed statistically higher fluoride release compared to control group in the first day $(p<0.05)$. However, in the $21^{\text {th }}, 28^{\text {th }}, 29^{\text {th }}, 35^{\text {th }}$ and $42^{\text {th }}$ days there were no statistically significant differences between fluoride release amounts of all groups ( $p>0.05)$. The changes in fluoride release amounts of materials within different time periods were shown in Figure 1.

Table 1. Fluoride release (mean and standard deviation) from the experimental groups at different measurement days.

\begin{tabular}{|c|c|c|c|c|c|c|c|c|c|}
\hline & 1st Day & 2nd Day & 7th Day & 14th Day & 21th Day & 28th Day & 29th Day & 35th Day & 42th Day \\
\hline Control & $36,0 \pm 4,0^{A, b}$ & $18,1 \pm 1,2^{\mathrm{B}, \mathrm{b}}$ & $5,9 \pm 0,8^{c, b}$ & $3,6 \pm 0,8^{\mathrm{D}, \mathrm{b}}$ & $3,0 \pm 0,5^{\mathrm{D}, \mathrm{a}}$ & $3,1 \pm 0,8^{\mathrm{D}, \mathrm{a}}$ & $9,5 \pm 1,0^{\mathrm{E}, \mathrm{a}}$ & $2,9 \pm 0,6^{\mathrm{D}, \mathrm{F}, \mathrm{a}}$ & $3,0 \pm 0,5^{\mathrm{D}, \mathrm{F}, \mathrm{a}}$ \\
\hline
\end{tabular}

${ }^{*}$ Different capital letters in the same row are significantly different $(P<0.05)$.

${ }^{* *}$ Different lowercase letters in the same column are significantly different $(P<0.05)$. 


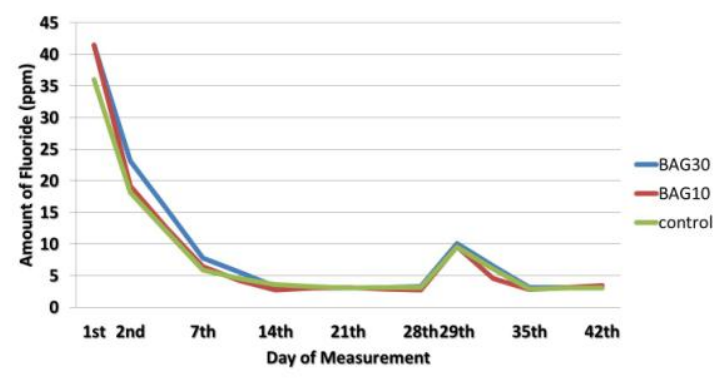

Figure 1. The changes in fluoride release amounts of experimental materials within different time periods.

\section{Mechanical properties}

The mean and the standard deviations of all groups for surface microhardness and surface roughness tests are presented in Table 2.

BAG30 and BAG10 presented statistically significant higher values for surface microhardness compared to control group $(p<0.05)$. However, there was no statistically significant difference could be observed between the BAG30 and BAG10 ( $p>0.05$ ).

Surface roughness of BAG30 and BAG10 was significantly higher than the control group $(p<0.05)$. In addition; there were no significant difference between BAG30 and BAG10 ( $p>0.05)$.

Table 2. The mean and the standard deviations of experimental groups for surface microhardness and surface roughness tests.

\begin{tabular}{|c|c|c|}
\hline & $\begin{array}{c}\text { Surface } \\
\text { microhardness } \\
(\text { VHN) }\end{array}$ & $\begin{array}{c}\text { Surface } \\
\left.\text { roughness ( } \mathbf{R}_{\mathbf{a}}\right)\end{array}$ \\
\hline BAC30 & $63,71 \pm 13,06^{\mathrm{a}}$ & $0,266 \pm 0,050^{\mathrm{a}}$ \\
\hline BAC10 & $59,06 \pm 11,19^{\mathrm{a}}$ & $0,228 \pm 0,052^{\mathrm{a}}$ \\
\hline Control & $38,31 \pm 6,04^{\mathrm{b}}$ & $0,186 \pm 0,042^{\mathrm{b}}$ \\
\hline
\end{tabular}

*Different lowercase letters in the same column are significantly different $(\mathrm{P}<0.05)$.

\section{DISCUSSION}

In recent years, there has been an increasing attention and interest in the use of bioactive materials in dentistry. ${ }^{10}$ Considering the current literature, numerous studies mentioned the use of bioactive materials to improve the properties of dental materials. ${ }^{15-17}$ Accordingly, many researchers have studied the effect of BAG incorporated into dental restorative materials on dental hard tissues and also the effect on the mechanical behavior of dental materials. ${ }^{10,11}$ The mec- hanical and physical properties of fissure sealants containing BAG were also investigated. The researchers claimed that, BAG containing pit and fissure sealant materials are promising for the protection of tooth structure from acid attacks. ${ }^{18}$ Also, it is demonstrated that, BAG containing fissure sealants are effective against microleakage and secondary caries. ${ }^{19}$ Therefore, the purpose of the present study was to evaluate the chemical and mechanical properties of a glass ionomer based fissure sealant containing different proportions of BAG.

Several studies have emphasized that fillers in the GIC could have either adverse or beneficial effects on the physical properties of cements. ${ }^{13}$ The addition of fillers to increase the bioactivity and antibacterial properties usually results with a decrease on mechanical strength. ${ }^{20-22}$ There are some studies reported the antibacterial properties and remineralization effects of BAG incorporated in GIC. ${ }^{9,10,12}$ It is reported that, the addition of BAG improves the bioactivity of the GIC by formation of an apatite layer. Also, BAG containing GICs may have several advantages such as remineralization of demineralized tooth structure and adhesion to hard tissues. ${ }^{23}$ However, some of the mechanical properties of this combination, including its fluoride release pattern have not yet been evaluated.

Fluoride release ability is one of the most important characteristics of GICs. ${ }^{1,3}$ Previous studies have described various different methods to detect fluoride release level of the dental materials. Among these methods, ion specific electrode is a simple and practical procedure and is preferred frequently. ${ }^{22,24}$ Based on the changes of fluoride release levels at a time, it is emphasized that especially glass ionomer based materials present a specific model. While a high level fluoride release from these materials was observed at first 24 hours, these amounts critically decrease on second day and later they progress more stable. Thus it is advised that measurement of the fluoride release from dental materials should be performed more frequently on first days. This effect of glass ionomer based materials which is observed on first day is called burst effect and such fluoride release patterns have two different paths to manifest themselves. First of the paths: is the release (burst effect) by the elution effect the fluoride remained on surfaces after the setting of the material, and the

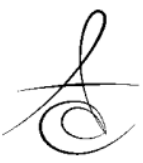


second path is fluoride release from material by diffusion. Fluoride release mediated by diffusion takes place in lower amounts but lasts for a long period. ${ }^{25,26}$

In direction with literature, highest amount of fluoride release for all groups was obtained on first day with the 'burst effect' in the present study, and a significant decrease on fluoride release was detected in the upcoming days. Intergroup evaluations for first measurements showed that BAG30 released higher fluoride ratios compared to other groups as expected. The reason of this condition; is considered as the enhancement of ion exchange due to increased ion mobility by bioactive glass which has high bioactivity and accordingly the enhancement of fluoride release. When the groups with addition of different ratios of bioactive glass were investigated, there was an analogy between the amounts of bioactive glass and fluoride release. Yli-Urpo et al. ${ }^{27}$ added different ratios of bioactive glass to glass ionomer based materials and examined the releases of silica, calcium, phosphorus and fluoride from these materials. As a result of the study they detected that as the bioactive glass amount increases, ion release also increases. The results of the present study also supports aforementioned findings.

When the data obtained in other measurement days of the present study were examined; fluoride release of all material groups were on same level on the measurements performed after day 7. Similarly, the presence of no significant difference between the groups after day 29 where recharging takes place, showed that incorporation of bioactive glass did not influence the recharging mechanism of glass ionomer based fissure sealants.

One of the important parameters that is used for the in vitro evaluation of dental materials is surface roughness. The plaque accumulation increases since the roughness on surface of restorative materials causes bacteria retention, and this situation makes it easier the abrasion of restoration, decreases the gloss of restoration and increases the color change of restoration. Because of this reason the surface roughness of the material used influences the long term clinical success of a restoration. ${ }^{28,29}$

In addition to the dimension of filler particles in glass ionomer based restorative materials, the filler quantity and the bonding of the filler material with liquid part also have influence on surface roughness. ${ }^{29}$
In the present study, it is ensured that the particle dimension is equal for all groups by subjecting to milling process the bioactive glass added glass ionomer based fissure sealants with bioactive glass addition at different ratios. According to the data obtained as the result of the study, when the materials modified by addition of different ratios of bioactive glass are compared with control group, it is determined that such modified materials are having higher roughness values. It is seen that this increase in the roughness values of tested materials shows a parallelism with the increase in filler quantities. It is thought that this situation is originating since the larger dimension particles are not eliminated even though materials with average particle dimension of $0,7 \mu \mathrm{m}$ are obtained as the result of milling process and the powder portion of the produced material doesn't have fully homogenous particle dimension. For this reason, it is predicted that the bioactive glass particles that will be incorporate with the glass ionomer based fissure sealant material which are more homogenous and having smaller dimension will avoid the disadvantage that it will create regarding the surface roughness. At the same time, it also predicted that the bonding between the bioactive glass particles and polyacrylate matrix is weak, and the fact that the bioactive glass particles are acting like filler particle is another factor increasing the roughness values.

Surface hardness tests are deemed important since they are able to give information regarding the physical properties of restorative materials. ${ }^{30}$ When the surface hardness values of glass ionomer based fissure sealants modified with bioactive glass at different ratios used in this study are investigated from statistical point of view, it is determined that the groups modified by bioactive glass are showing higher hardness values in comparison to control group. In the light of obtained data, it is estimated that the increase in surface hardness of materials is originating from the increase in filler quantity inside the glass ionomer based fissure sealants. When the results are studied; it is seen that optimum values are ensured for surface hardness measurements of glass ionomer based fissure sealant by addition of $10 \%$ of bioactive glass. It is determined that the surface hardness value increases more by increasing this ratio to $30 \%$, however it is also determined that this increase is not statistically significant. 
According to the results of the present study, the null hypothesis was partially accepted. The incorporation of BAG particles into glass ionomer based fissure sealant was significantly improved the surface microhardness properties of material. Also, incorporation of BAG particles with the proportion of $\% 10$ did not adversely affect the surface roughness of glass ionomer based fissure sealant material. However, requested long term and high levels of fluoride release was not accomplished with addition of bioactive glass to glass ionomer based fissure sealant materials. Besides, it is also known that, the anticariogenic effects of bioactive glass do not happen only by way of fluoride release. Within the limitations of this study; it can be concluded that, glass ionomer based fissure sealant materials containing BAG particles are promising dental materials with adequate mechanical properties. Considering the remineralizing and antibacterial properties of BAG, there is need for advanced in vitro and in vivo tests in order to determine the long term anticariogenic and antibacterial effects of this material.

Emre KORKUT: https://orcid.org/0000-0001-6976-3071 Murat S. BOTSALI: ORCID ID: 0000-0002-5719-5430 Yağmur ŞENER: ORCID ID: 0000-0003-1777-1197

\section{REFERENCES}

1. Croll TP, Nicholson JW. Glass ionomer cements in pediatric dentistry: review of the literature. Pediatr Dent 2002;24:423-9.

2. Simonsen RJ, Neal RC. A review of the clinical application and performance of pit and fissure sealants. Aust Dent J 2011;56:45-58.

3. Berg JH, Croll TP. Glass ionomer restorative cement systems: an update. Pediatr Dent 2015;37:116-24.

4. Forsten L. Fluoride release and uptake by glass ionomer and related materials and clinical effect. Biomaterials 1998;19:503-8.

5. Haznedaroğlu E, Menteş A. Scanning electron microscope and microhardness evaluation of GIC sealant application after different enamel treatment procedures. Atatürk Üniv Diş Hek Fak Derg 2013;21:177-86.

6. Smith DC. Development of glass-ionomer cements systems. Biomaterials 1998;19:467-78.

7. Hench LL. The story of Bioglass. J Mater Sci: Mater Med 2006;17:967-78.
8. Kaur G, Pandey OP, Singh K, Homa D, Scott B, Pickrell G. A review of bioactive glasses: the structure, properties, fabrication, and apatite formation. J Biomed Mater Res 2014;102:254-74.

9. Hu S, Chang J, Liu M, Ning C. Study on antibacterial effect of $45 \mathrm{~S} 5$ bioglass. J Mater Sci: Mater Med 2009;20:281-6.

10. Imazato $\mathrm{S}$. Bio-active restorative materials with antibacterial effects: new dimension of innovation in restorative dentistry. Dent Mater J 2009;28:119.

11. Matsuya S, Matsuya Y, Ohta M. Structure of bioctive glass and its application to glass ionomer cement, Dent Mater J 1999;18:155-66.

12. Mehta $A B$, Kumari V, Jose $R$, Izadikhah V. Remineralization potential of bioactive glass and casein phospopeptide-amorphous calcium phosphate on initial carious lesion: An in-vitro pH-cycling study. J Conserv Dent 2014;17:3-7.

13. Chen S, Cai Y, Engqvist H, Xia W. Enhanced bioactivity of glass ionomer cement by incorporating calcium silicates. Biomatter 2016;6:e1123842.

14. Valanezhad A, Odatsu T, Udoh K, Shiraishi T, Sawase $T$, Watanabe I. Modification of resin modified glass ionomer cement by addition of bioactive glass nanoparticles. J Mater Sci: Mater Med 2016;27:e3.

15. Khvostenko D, Mitchell JC, Hilton TJ, Ferracane JL, Kruzic JJ. Mechanical performance of novel bioactive glass containing dental restorative composites. Dent Mater 2013;29:1139-48.

16. Profeta AC, Mannocci F, Foxton RM, Thompson I, Watson TF, Sauro S. Bioactive effects of a calcium/sodium phosphosilicate on the resin dentine interface: a microtensile bond strength, scanning electron microscopy, and confocal microscopy study. Eur J Oral Sci 2012;120:353-62.

17. Ana ID, Matsuya S, Ohta M, Ishikawa K. Effects of added bioactive glass on the setting and mechanical properties of resin-modified glass ionomer cement. Biomaterials 2003;24:3061-7.

18. Yang YS, Piao ZY, Kim MS, Lee KY, Kim NK, Kim MK. Acid neutralizing, mechanical and physical properties of pit and fissure sealants containing melt-derived 4555 bioactive glass. Dent Mater 2013;29:1228-35. 
19. Yang YS, Kwon SJ, Kim NK, Kim MK. Enamel Surface with Pit and Fissure Sealant Containing 45S5 Bioactive Glass. J Dent Res 2016;95:550-7.

20. Prabhakar AR, Prahlad D, Kumar SR. Antibacterial activity, fluoride release and physical properties of an antibiotic-modified glass ionomer cement. Pediatr Dent 2013;35:411-5.

21. Lucas EM, Arita K, Nishino M. Toughness, bonding and fluoride release properties of hydroxyapatite added glass ionomer cement. Biomaterials 2003;24:3787-94.

22. Tiwari S, Nandlal B. Comparative evaluation of fluoride release from hydroxyapatite incorporated and conventional glass ionomer cement: an in vitro study. J Indian Soc Pedod Prev Dent 2012;30:2847.

23. De Caluwé T, Vercruysse CW, Ladik I, Convents R, Declercq $\mathrm{H}$, Martens LC, Verbeeck RM. Addition of bioactive glass to glass ionomer cements: Effect on the physico-chemical properties and biocompatibility. Dent Mater 2017;33:e186-e203

24. Guida A, Hill RG, Towler Mr, Eramo S. Fluoride release from model glass ionomer cements. J Mater Sci: Mater Med 2002;13:645-9.

25. Paschoal MA, Gurgel CV, Rios D, Magalhaes AC, Buzalaf MA, Machado MA. Fluoride release profile of a nanofilled resin-modified glass ionomer cement. Braz Dent J 2011;22:275-9.

26. Wiegand A, Buchalla W, Attin T. Review on fluoride releasing restorative materials fluoride release and uptake characteristics, antibacterial activity and influence on caries formation. Dent Mater 2007;23:343-62.

27. Ylı-Urpo H, Vallıttu PK, Narhı TO. Release of silica, calcium, phosphorus, and fluoride from glass ionomer cement containing bioactive glass. J Biomater Appl 2004;19:5-20.

28. De Witte AM, De Maeyer EA, Verbeeck RM. Surface roughening of glass ionomer cements by neutral NaF solutions. Biomaterials 2003;24:1995-2000.

29. Silva RC, Zuanon AC. Surface roughness of glass ionomer cements indicated for atraumatic restorative treatment. Braz Dent ] 2006;17:106-9.

30.Yap AU, Cheang PH, Chay PL. Mechanical properties of two restorative reinforced glassionomer cements. J Oral Rehabil 2002;29:682-8.

\section{Yazışma Adresi}

Dr. Emre Korkut

Karacigan mah. Ankara cad. no: 74/A

Karatay/Konya/TURKEY

tel: +905054544162

fax:+90322200045

e-mail: ekorkut@konya.edu.tr 